Original Russian Text (C) 2019 N.V. Baranovskiy, A.V. Zakharevich, published in Forest Science Issues Vol. 2, No. 1, pp. 1-15

DOI 10.31509/2658-607X-2020-3-1-1-9

\title{
EXPERIMENTAL MODELING OF SPRUCE NEEDLES IGNITION BY A CARBONACEOUS PARTICLE HEATED TO HIGH TEMPERATURES
}

\author{
N.V. Baranovskiy", A.V. Zakharevich \\ Tomsk Polytechnic University \\ Lenin Av., 30, Tomsk, 634050, Russian Federation \\ *E-mail: firedanger@yandex.ru \\ Received 11 March 2019
}

Forest fires occur as a result of natural and man-made causes. It is known that particles heated to high temperatures are a common source of high temperature. The purpose of the work is the physical simulation of the ignition of typical forest fuel (spruce needles) by a carbonaceous particle heated to high temperatures and the identification of the typical ignition conditions of forest fuel. Every year, field observations and collection of forest fuel samples for experimental studies are carried out in the Timiryazevskiy forestry of the Tomsk Region. Typical forest fuel (spruce needles) is considered. The sources of heating during the ignition of forest fuel were simulated by the particles made of graphite in the shape of a parallelepiped with characteristic dimensions in three coordinate directions $(14 \mathrm{~mm}, 8 \mathrm{~mm}, 8 \mathrm{~mm})$. The weight of such a graphite particle was $1.3 \mathrm{~g}$. Experiments were performed in the range of changes in the initial temperatures $T_{0}$ from $1113 \mathrm{~K}$ to $1273 \mathrm{~K}$. Numerical analysis shows that at a low sedimentation height, the particle retains its heat content to the maximum and cools down only in the near-surface layers. Initially, the mechanism of ignition as a result of the action of a burning graphite particle was investigated. The physical mechanism of the ignition of the forest fuel layer is established when a carbonaceous particle heated to high temperatures falls out in a flameless mode. A series of experiments were carried out and the dependence of the ignition delay on the initial temperature of the particle was obtained. The analysis showed that the dependence of the ignition delay on the initial temperature of a particle can be approximated to a first approximation by a straight line. The obtained results can be used for the development and verification of mathematical models to simulate the ignition of forest fuel by the particle heated to high temperatures.

Key words: forest fuel, mechanism, experimental modeling, ignition delay, particle, spruce

Forest fires occur due to natural and manmade causes (Hu and Zhou, 2014). The main natural cause is the impact of a cloud-toground lightning discharge, which results in the fragmentation of wood (Baranovskiy et al., 2017). As a result, wood particles heated to high temperatures are formed. Such particles can fall onto a layer of forest fuel and cause it to ignite (Suzuki and Manzello, 2019). As a result, a surface forest fire occurs
(Grishin, 1997). Another scenario corresponds to anthropogenic impacts when there are still fires left in the forested area (Yanko, 2005). When wood cracks in a fire, its small particles can move to a layer of forest fuel near the fire and cause ignition. As a result, the occurrence of a surface forest fire is possible. It should also be noted that the formation of such particles is possible directly during active forest fires (Manzello et al., 
2006). Subsequently, such particles, as a result of vertical and horizontal transport, can leave the forest fire zone and are transported to a distance of several hundred meters (Terebnev et al., 2007). Then, such particles settle on a layer of forest fuel and cause a new fire. This is exactly how spotted forest fires occur (Grishin, 1981).

To develop next-generation systems for forecasting forest fire danger, it is necessary to take into account the physicochemical processes that occur when the layer of forest fuel is ignited. To identify the physical mechanism and carry out subsequent verification of such models, it is necessary to conduct experiments for the physical modeling of the ignition of typical forest fuel by a particle heated to high temperatures, which is a widespread source of high temperature.

The aim of the research is the physical modeling of the ignition of typical forest fuel (spruce needles) by a carbonaceous particle heated to high temperatures and the identification of the ignition conditions for the typical forest fuel.

\section{STUDY AREA}

The ecological system of forests of the Russian Federation occupies 1.2 billion hectares of territory and contains about $25 \%$ of the forest resources of the entire planet. Russian forests are not only an economic but also an important environmental resource, since the Russian Federation provides the annual carbon storage of 29 billion tons. The global processes of regulating the state of the environment, biodiversity, climate, and river flows are significantly affected by Russian forests (Kuznetsov et al., 2005).

The Tomsk Region, especially its northern part, is a fairly typical forest-covered territory of the boreal zone. Through this example, a fairly general description of the conditions for the occurrence of fires is possible. The region has large forest resources. The land-forest fund occupies $90.5 \%$ of its entire territory. An area of 17 million hectares is covered with tree species, including 9.9 million hectares of coniferous trees (Panevin, 2006). The main relief types within the Tomsk Region are the watershed plains and river valleys along with the hollows of the ancient runoff (Evseeva and Zemtsov, 1990). Dividing plains are represented by positive and negative morphostructures.

Forests of the region are located in the river basin. The $\mathrm{Ob}$ River is situated on an exceptionally flat territory with excess moisture and is of great environmental importance (Panevin, 2006). Relatively harsh climatic conditions determine the rather limited species composition of forests. The most common types of forest formers are common pine, Siberian cedar, Siberian spruce, Siberian fir, saggy and fluffy birch, Siberian aspen, and larch (Panevin, 2006; Gorina, 2008).

The fire danger of the Tomsk Region forests is determined by the presence of a significant proportion of coniferous forests, developed high-temperature ground cover and hot, dry summers. The climate of the Tomsk Region is sharply continental of the boreal type (Gorina, 2008). In territories with a continental climate, conditions especially favorable for the occurrence of forest fires are created (Kurbatsky, 1964). Depending on weather conditions, all three peaks of seasonal incidence are expressed in the forests of the region: a spring wave of fires, summer steady fires and autumn fires (Panevin, 2006).

A feature of the forests of the Tomsk Region is the presence of combustible material in all stands. Mostly surface fires develop in the region $(98.5 \%) ; 1.1 \%$ of incidents and $12.5 \%$ of the burned-out area are accounted for by crown fires, and underground fires occur even less frequently (Panevin, 2006). The share of fires caused by anthropogenic reasons is quite stable over the years, and fires from a lightning discharge are cyclical. Periods with massive thunderstorms give way to calmer fires. The combustibility of the region's forests also varies significantly over the months of the fire danger season. The most "burning" months are June and July. The duration of the fire danger season according to the weather conditions is from 137 to 161 days (Panevin, 2006). According to Rosleskhoz, the statistics of forest fires in the Tomsk Region suggests that approximately 200 forest fires are caused by anthropogenic factors and about 75 forest fires result from thunderstorm activity (as for 
2016). Part of the fires arises as a result of the transition of agricultural burnings to forested areas.

Annually, field observations and collection of forest fuel samples for experimental studies are carried out in the Timiryazevskiy forestry of the Tomsk Region. The specified forestry of the Tomsk Forest Management is located between two large rivers ( $\mathrm{Ob}$ and Tom) in the territory of three administrative districts of the Tomsk Region - Tomsky, Shegarsky, and Kozhevnikovsky. The length of the forestry territory from North to South is $64 \mathrm{~km}$, from West to East $50 \mathrm{~km}$. Forests of the forestry are mainly represented by a single forest, except for the isolated near-village pine forests of the settlements of Zorkaltsevo, Nizhne-Sechenovo, and Gubino (Matsenko et al., 1999).

According to the forest vegetation zoning of Western Siberia, the territory of the
Timiryazevskiy forestry of the Tomsk Region belongs to the zone of the southern taiga (the Ob-Tomsk pine and pine forest-growing district). According to the agroclimatic zoning of the Tomsk Region adopted by the Tomsk branch of Sibgiprozem, the forestry area is classified as a moderately humid area. The growing season is 120 days. The predominant main breed is pine $(39.6 \%)$, aspen $(26.2 \%)$ and birch (21.2\%); cedar, larch, spruce, and fir account for 13\% (Matsenko et al., 1999). For several years, the former Kaltayskoye Forestry as the Kaltayskoye Local Forestry was part of the Timiryazevskiy forestry.

MATERIALS AND METHODS
The experimental facility and
methodology described in detail in
(Zakharevich et al., 2008; Kuznetsov et al.,
2008) were used. The experimental facility is
illustrated in Figure 1.

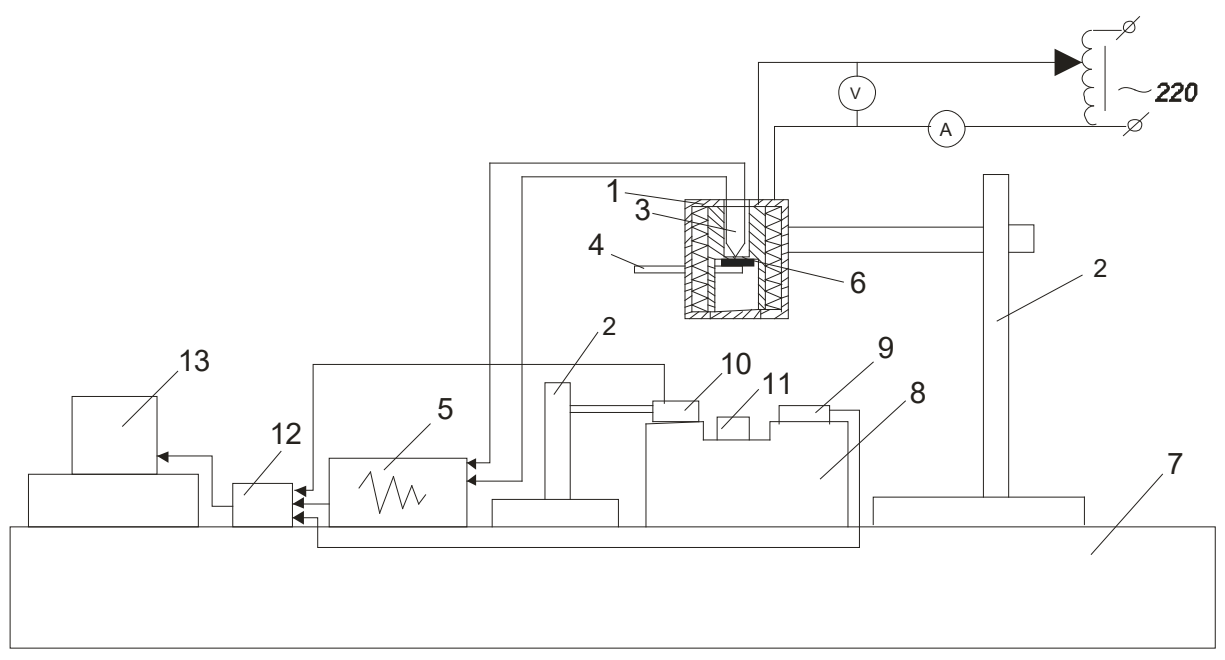

Figure 1. Scheme of the experimental facility: 1 - heating device, 2 - tripod, 3 - chromel-alumel thermocouple, 4 - ceramic rod, 5 - temperature control device UKT38, 6 - metal particle, 7 working surface of the experimental setup, 8 - fireproof platform, 9 - radiation detector and flame recorder, 10 - emitter, 11 - vertical glass cylindrical vessels, 12 - analog-to-digital converter (ADC), 13 - personal computer (Zakharevich et al., 2008; Kuznetsov et al., 2008).

The sources of heating during forest fuel ignition were modeled by parallelepipedshaped particles made of graphite with characteristic dimensions in three coordinate directions (14 mm, $8 \mathrm{~mm}, 8 \mathrm{~mm})$. The weight of such a graphite particle was $1.3 \mathrm{~g}$. The experiments were carried out in the initial temperature range $\mathrm{T}_{0}$ from $1113 \mathrm{~K}$ to $1273 \mathrm{~K}$. This range was chosen in order to single out, firstly, the lower ignition limits of the investigated forest fuel. The upper temperature limit was chosen based on the conditions of ignition of a graphite particle in the air (a burning particle upon precipitation onto the forest fuel layer always caused its ignition). Numerical analysis shows that at a low separation height, the particle retains its maximum heat content to the maximum and cools down only in the surface layers. The central massive part of the particle during the 
deposition period does not cool down regardless of the separation height. As a result of the sedimentation of such a particle on a layer of ground forest fuel at the contact point, heat will flow into the surface layers of forest fuel. At subsequent times, the thermal decomposition and gas-phase ignition of forest fuel layer can occur. As a result, a surface forest fire may occur (Grishin et al., 1998; Podur et al., 2003).

The experiments were carried out according to the classical plan with randomization due to the fact that up to now no mathematical model has been defined that describes the relationship between the delay time of forest fuel ignition and the initial temperature of a local heating source. At a constant value of $\mathrm{T}_{0}, 5-7$ experiments were performed, the standard deviation and confidence intervals for determining $t_{\text {ign }}$ were calculated with a confidence probability of $\mathrm{P}=0.95$ (Ventsel, 1999). The normal distribution of the measured quantity (ignition delay time) was assumed. The experiments were carried out with a group of graphite particles identical in size and manufacturing conditions. Before the experiments, heat treatment of heating sources in an induction furnace was carried out to "burn" volatile compounds. Each particle was used in only one experiment, because its state (shape, size, and the structure of the surface layers) changed after the experiment. These changes were generally insignificant, but the particles were not reused to reduce the errors in the studies performed.

It should be noted that the carbonaceous particle ignition process is different from a similar process with a steel particle as a source of ignition. Single carbonaceous particles at high temperatures are characterized by a gasification process that occurs during the intense penetration of gas reagents through the porous structure of a particle (Vilensky and Khzmalyan, 1978; Golovina, 1983; Morell et al., 1990). That is, diffusion processes are important (it was shown (Samuilov et al., 2004) that diffusion phenomena have a significant influence on the gasification process for large particles and the transformation of components inside the particle, which leads to a change in the porous structure itself (Jones et al., 1999).

The type of global gasification reaction is as follows (Samuilov et al., 2004): $\mathrm{C}+\mathrm{CO}_{2}$ $\rightarrow$ 2CO. According to (Laurendau, 1978), this process involves a chain of reactions on the surface of pores:

$$
\begin{aligned}
& \mathrm{C}_{\mathrm{f}}+\mathrm{CO}_{2} \leftrightarrow \mathrm{C}(\mathrm{O})_{\mathrm{L}}+\mathrm{CO}, \\
& \mathrm{C}(\mathrm{O})_{\mathrm{L}} \rightarrow \mathrm{C}_{\mathrm{f}}+\mathrm{CO}, \\
& \mathrm{C}(\mathrm{O})_{\mathrm{L}} \leftrightarrow \mathrm{C}(\mathrm{O})_{\mathrm{S}}, \\
& \mathrm{C}(\mathrm{O})_{\mathrm{S}} \rightarrow \mathrm{C}_{\mathrm{f}}+\mathrm{CO},
\end{aligned}
$$

where $\mathrm{C}_{\mathrm{f}}, \mathrm{C}(\mathrm{O})_{\mathrm{L}}, \mathrm{C}(\mathrm{O})_{\mathrm{S}}$ are free active carbon centers, an oxygen atom connected to a carbon atom by a mobile ionic bond, and an oxygen atom forming a fixed carbonyl bond with a carbon atom, respectively. To date, new approaches to the study of the mechanism and laws of heterogeneous combustion and carbon gasification reactions have been developed (Golovina, 2002). If in the framework of the diffusion-kinetic theory of heterogeneous combustion and gasification of carbon, the laws of the process were judged by the behavior of only the gas phase, then now, along with the gas phase, changes in the solid phase are also taken into account. For this, the concept of active surface areas (ASAs) or, more broadly, reactive surface areas (RSAs) is introduced. The reactive surface is determined by the concentration of active carbon atoms, on which a carbonoxygen complex is formed, which gives a gaseous product upon decomposition (Golovina, 2002; Lizzo et al., 1990).

The preliminary placement of graphite particles in an induction furnace showed that in the temperature range 1113-1273 K, a graphite particle burned in a flame mode. The sedimentation of such a particle on the forest fuel layer also unambiguously leads to ignition. It is likely that the initial heating of a graphite particle is accompanied by the release of any volatile compounds that burn in the gas phase. The subsequent heating of the particle is not accompanied by the appearance of a flame around the particle. A series of preliminary experiments showed that a carbonaceous particle is characterized by its burnout over time. This can be explained by 
the processes of gasification of a carbonaceous particle considered above, as well as by the heterogeneous oxidation of carbon itself.

The object of the study was the model layers of a typical forest fuel (spruce needles with branches), which were formed in a refractory cuvette by means of a random stacking of branches with needles in a uniform layer. The characteristics of forest fuel:

a) the needles in appearance are green with a slight gray-brown tint;

b) the needles and branches of the current collection are practically not decomposed;

c) pre-dried material;

d) the main fraction consisted of needles with a size of (1.5-2) $\mathrm{cm}$ in the longitudinal and $(0.7-1.3) \mathrm{mm}$ in the transverse direction;

e) the fraction of twigs different from the main part of the needles was about $25 \%$.

\section{RESULTS AND DISCUSSION}

The following patterns of the process under study were established. Two options for the implementation of the ignition conditions are possible:

a) Initially, the mechanism of the occurrence of ignition as a result of the impact of a burning graphite particle was investigated. A carbonaceous particle, accompanied by a flame torch of combustion of volatile compounds, falls on the forest fuel layer, which is heated by three heat transfer mechanisms: conduction, convection, and radiation (most likely, convective and radiant transfer are the main ones in this ignition mechanism). Individual needles warm up and begin to thermally decompose with the release of gaseous pyrolysis products. The injection of gaseous combustible products and the ignition of forest fuel in the gas phase occurs. For the moment of ignition, the appearance of a second flame is characteristic (the first is formed as a result of the combustion of volatile products released by the particle). Then there is a combination of torches and the subsequent spread of flame along the forest fuel layer.

b) Fig. 2 shows typical video footage of the process of forest fuel layer ignition by a carbonaceous particle heated to high temperatures (flameless mode). After the initial stage of a short period of inert heating of the forest fuel layer, the thermal decomposition of the material begins with the release of gaseous pyrolysis products. In the contact zone, the needles from the heterogeneous layer of forest fuel decompose almost completely with a small coke residue that falls on the substrate. Thin branches are thermally decomposed in a thin surface layer. In a porous forest fuel medium, gaseous pyrolysis products are filtered to the heated surface of the layer and mixed with an oxidizing agent, and the gas mixture is heated, followed by ignition. In most experiments, a flame torch formed over a heated particle.

Fig. 3 shows the dependence of the ignition delay on the initial particle temperature with confidence intervals. The lower ignition temperature limit is highlighted. Unlike pine litter, the studied sample was characterized by an ordered distribution of individual needles, thin branches and often a fixed distance between them. The structure of the sample was characterized by porosity due to the ordered structure of the needles, as well as a large pore space due to the morphology of spruce branches, which led to rather high values of the standard deviations of the measurement results $t_{\text {ign }}$ from the average values. Due to this, in each particular experiment from a series of experiments at the same initial temperature, the heat exchange conditions between the ignition source and the forest fuel layer also differed.

An analysis of Fig. 3 shows that the dependence of the ignition delay on the initial particle temperature can be approximated, as a first approximation, by a straight line. However, a more qualitatively obtained experimental data describes a parabolic dependence. Earlier, a similar fact was established when studying the ignition processes of dry grass with a packing density corresponding to natural conditions. However, its further increase led to a linear dependence of the ignition delay on the initial temperature of the heated particle. The difference from the linear dependence was probably due to the non-identity of the processes of heat and mass transfer in a 
complex structurally inhomogeneous material. This is probably the reason for the deviation from the linear dependence in the case of studying spruce branches with needles.

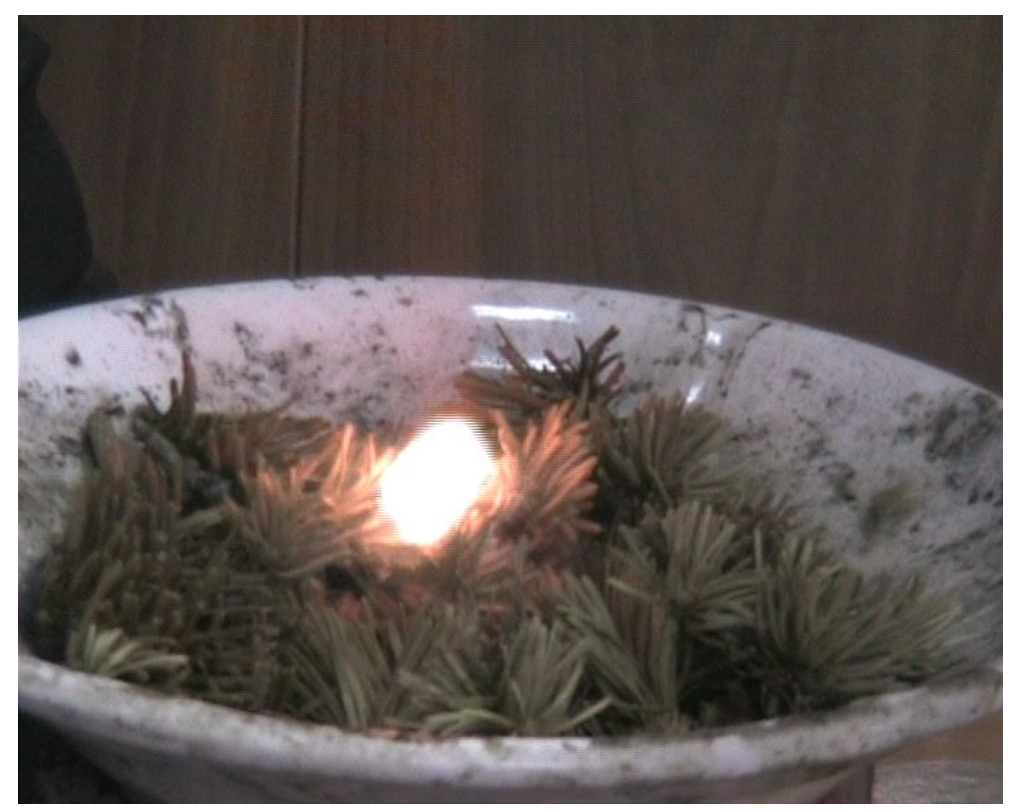

a)

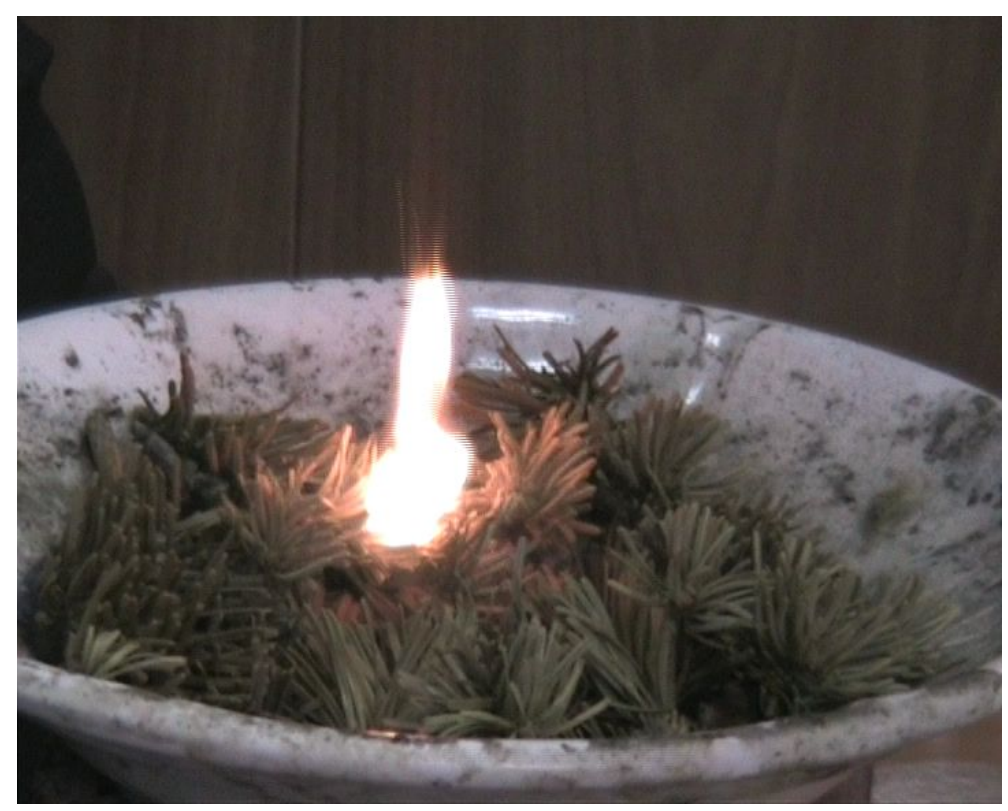

b)

Figure 2. Typical video footage of the forest fuel ignition by a particle heated to high temperatures at different points in time: a) $\mathrm{t}=0.08 \mathrm{~s}$ - inert heating of the forest fuel layer; b) $\mathrm{t}=0.24 \mathrm{~s}-$ the appearance of a microtorch of flame.

It should be noted that the performed experimental studies showed the high stability of the ignition of forest fuel with multiscale porosity by a single carbonaceous particle heated to high temperatures. The development of the ignition process is fairly well demonstrated by the typical videogram of the experiment 


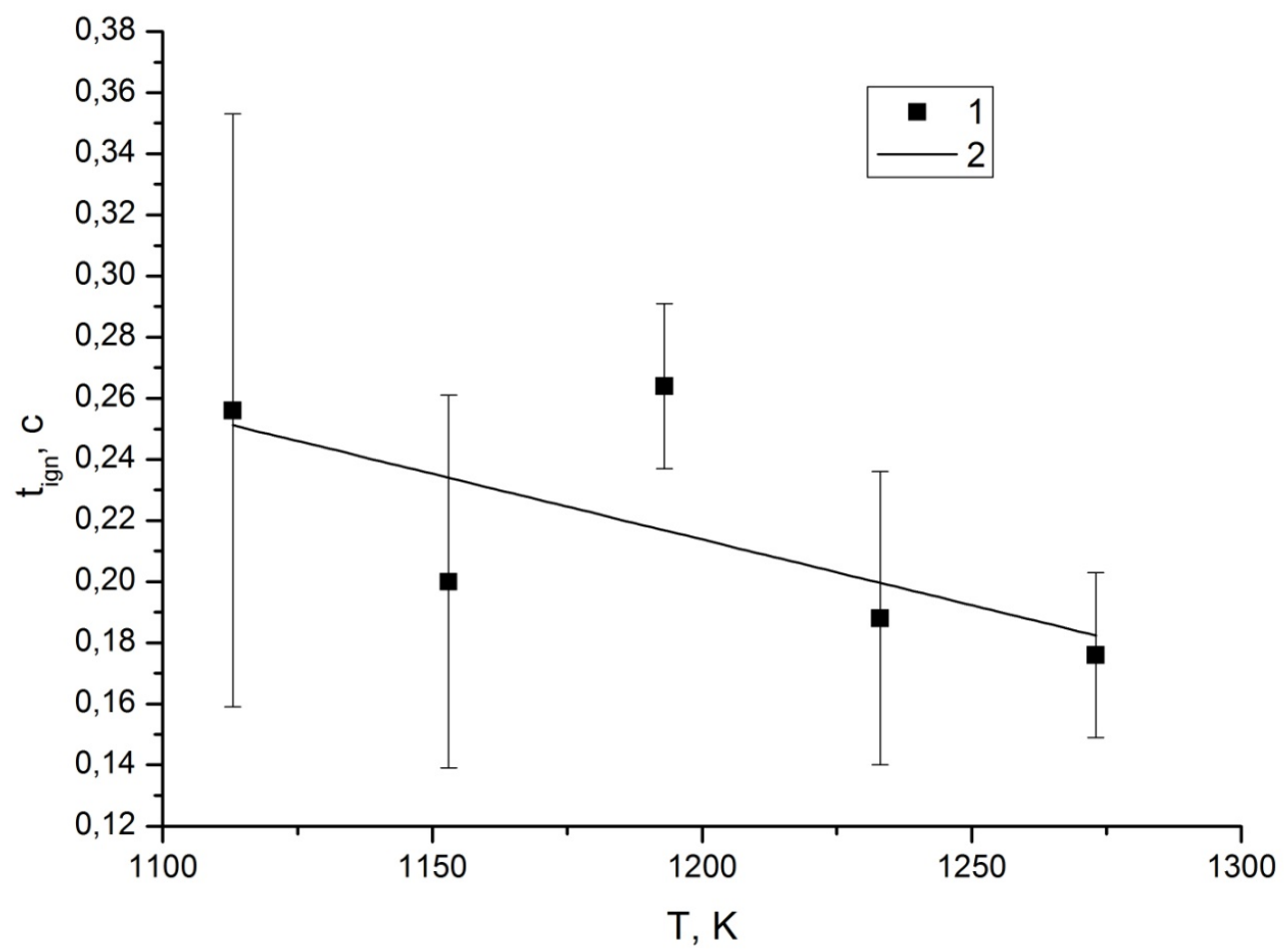

Figure 3. Dependences of the forest fuel ignition delay on the initial particle temperature: 1,2- the averaged values and an approximating straight line (particle $\mathrm{h}=14 \mathrm{~mm} ; \mathrm{x} 1=8 \mathrm{~mm} ; \mathrm{x} 2=8 \mathrm{~mm}$; $\mathrm{m}=1.3 \mathrm{~g})$.

It should be specially noted that the experimental values of $t_{\text {ign }}$ (Fig. 3 ) at $T_{0} 1273$ $\mathrm{K}$ can be compared with the values of the ignition delay of a typical liquid fuel kerosene under adequate heat exposure conditions (Zakharevich, 2008). For kerosene, $t_{i g n}$ is more than two times higher than the similar value for the litter of conifers. In this case, the lower limit values of the ignition temperatures of kerosene are almost $100 \mathrm{~K}$ higher than those shown in Fig. 3. The correlation between the characteristic ignition delays of the litter of coniferous trees and typical liquid fuels established by the experimental results is due to the peculiarities of heat and mass transfer in the heated layer and on the surface of these combustible substances under local thermal exposure. For example, the research results (Kuznetsov and Strizhak, 2008; Kuznetsov and Strizhal, 2009;
Kuznetsov and Strizhak, 2009) show that when heating both films and large masses of liquid fuels, a significant part of the supplied heat energy is spent on an energy-intensive process of formation of fuel vapor. The heat of phase transition (the evaporation of any liquid fuel) is significantly (more than 10 times) higher than the heat spent on the gasification of forest fuel (thermal decomposition). Accordingly, a longer heating time of liquid fuel is required in comparison with forest fuel in order to initiate a chemical combustion reaction.

\section{CONCLUSION}

Additional experiments were conducted with a typical forest fuel of the Tomsk Region (spruce branches covered with needles), which showed the need for the further improvement of the mathematical models of 
forest fuel ignition by a local heating source. An analysis of the results shows that for forest fuel samples with large pore spaces, the linear dependence of the ignition delay time on the initial temperature of the heated particle is applicable only to a first approximation. At the next stage, an improved mathematical model of forest fuel ignition should be

\section{REFERENCES}

Baranovskiy N.V., Kuznetsov G.V., Nemova T.N., High temperature wood particles formation caused by the cloud-to-ground lightning discharge through the coniferous tree trunk, Far East Journal of Mathematical Sciences, 2017, Vol. 102, pp. 1033-1044.

Evseeva I.S., Zemtsov A.A., Rel'yefoobrazovaniye $v$ lesobolotnoy zone Zapadno-Sibirskoy ravniny (Relief formation in the forest-swamp zone of the Zapadno-Siberian plain), Tomsk: Publishing house Tom. University, 1990, $242 \mathrm{p}$.

Golovina E.S., Vysokotemperaturnoye goreniye $i$ gazifikatsiya ugleroda (Hightemperature combustion and gasification of carbon), Moscow: Energoatomizdat, 1983.

Golovina E.S., Issledovaniye geterogennogo goreniya i gazifikatsii ugleroda i tverdogo topliva (Obzor) (Study of Heterogeneous Combustion and Gasification of Carbon and Solid Fuel (Review), Fizika goreniya $i$ vzryva, 2002, Vol. 38, No. 4, pp. 25-34.

Gorina N.V., Lesnyye pozhary (Forest Fires), Bezopasnost' zhiznedeyatel'nosti, 2008, No. 1, pp. 57-60.

Grishin A.M., Matematicheskiye modeli lesnykh pozharov (Mathematical models of forest fires), Tomsk: Tomsk University Press, 1981, $278 \mathrm{p}$.

Grishin A.M., Mathematical modeling of forest fire and new methods of fighting them. Russia. Tomsk: Publishing House of the Tomsk State University, 1997, 390 p.

Grishin A.M., Dolgov A.A., Zima V.P., Kryuchkov D.A., Reino V.V., Subbotin A.N., Tsvyk R.Sh., Ignition of a layer of combustible forest materials, Combustion, Explosion and Shock Waves, 1998, Vol. 34, pp. 613-620. developed taking into account small and large pores in the forest fuel layer.

\section{ACKNOWLEDGEMENTS}

The study was supported by the Russian Foundation for Basic Research and the Administration of the Tomsk Region. Scientific project No. 16-41-700831.

Hu T., Zhou G. Drivers of lightning- and human-caused fire regimes in the Great Xing'an Mountains, Forest Ecology and Management, 2014, Vol. 329, pp. 49-58.

Jones J.M., Pourkashanian M., Rena C.D., Williams A., Modelling the relationship of coal structure to chair porosity, Fuel, 1999, Vol. 78, pp. 1737-1744.

Kuznetsov G.V., Zakharevich A.V., Maksimov V.I., Zazhiganiye dizel'nogo topliva odinochnoy "goryachey" metallicheskoy chastitsey (Ignition of diesel fuel by a single "hot" metal particle), Pozharovzryvobezopasnost', 2008. Vol. 17, No. 4, pp. 28-30.

Kuznetsov G.V., Strizhak P.A., Nagretyye do vysokikh temperatur chastitsy metalla kak istochniki lokal'nykh vozgoraniy zhidkikh veshchestv (Metal particles heated to high temperatures as sources of local ignitions of liquid substances), Pozharnaya bezopasnost', 2008, No. 4. pp. 72-76.

Kuznetsov G.V., Strizhak P.A., Modelirovaniye vosplameneniya zhidkogo veshchestva goryachey chastitsey (Simulation of the ignition of a liquid substance by a hot particle), Khimicheskaya fizika, 2009, Vol. 28, No. 5, pp. 91-98.

Kuznetsov G.V., Strizhak P.A., 3D Problem of heat and mass transfer at the ignition of a combustible liquid by a heated metal particle, Journal of Engineering Thermophysics, 2009, Vol. 18, No 1, pp. 72-79.

Kuznetsov V.I., Kozlov N.I., Khomyakov P.M., Matematicheskoye modelirovaniye evolyutsii lesa dlya tseley upravleniya lesnym khozyaystvom (Mathematical modeling of forest evolution for forest management purposes), Moscow: LENAND, 2005. $232 \mathrm{p}$. 
Kurbatskiy N.P. Pozhary taygi, zakonomernosti ikh vozniknoveniya $i$ razvitiya (The Fires of the Taiga, the Patterns of Their Origin and Development): Author's abstract. diss. ... doctor agricultural sciences / ILID SO of the USSR. Krasnoyarsk, 1964. 38 p.

Laurendau N.M., Heterogeneous kinetics of coal char gasification and combustion, Prog. Energy and Combust. Sci., 1978, Vol. 4, No 4., pp. 221-270.

Lizzo A., Hong J., Radovic R., On the kinetics of carbon (char) gasification: reconciling model with experiments, Carbon, 1990, Vol. 28, No 1., pp. 7-19.

Matsenko V.V., Sokolov A.Ya., Kalinin S.I., General'nyy plan protivopozharnogo ustroystva lesov (Master Plan for Fire Protection Plants), Vol. 1., Explanatory note, 5-99.14-17-PM / State Design and Survey Institute «Rosgiproles», Altai branch. Barnaul, 1999, 139 p.

Manzello S.L., Cleary T.G., Shields J.R., Yang J.C., Ignition of mulch and grasses by firebrands in wildland-urban interface fires, International Journal of Wildland Fire, 2006, Vol. 15, pp. 427-431.

Morell J.I., Amundson N.R., Park S.K., Dynamics of a single particle during char gasification, Chem. Eng. Sci. 1990, Vol. 45, No 2, pp. 387-401.

Panevin V.S., Lesa $i$ lesnoye khozyaystvo Tomskoy oblasti (Forests and Forestry of the Tomsk Region), Tomsk: Publishing house Tom. University, 2006, 126 p.

Podur J., Martell D. L., Csilagg F., Spatial patterns lightning-caused forest fires in Ontario 1976-1998, Ecological Modelling, 2003, Vol. 164, No 1, pp. 1-20.

Samuilov E.V., Faminskaya M.V., Golovina E.S., Model' i raschet protsessa gazifikatsii odinochnoy uglerodnoy chastitsy (Model and calculation of the process of gasification of a single carbon particle),
Fizika goreniya i vzryva, 2004, Vol. 40, №

1. pp. 86-94.

Suzuki S., Manzello S.L., Investigating effect of wind speeds on structural firebrand generation in laboratory scale experiments, International Journal of Heat and Mass Transfer, 2019, Vol. 130, pp. 135-140.

Terebnev V.V., Artemyev N.S., Podgrushny A.V., Protivopozharnaya zashchita $i$ tusheniye pozharov. Kniga 5. Lesa, torfyaniki, lesosklady, (Fire protection and extinguishing fires. Book 5. Forests, peatlands, forest stands), Moscow: Publishing house «Pozhnauka», 2007. 358 p.

Ventsel E.S., Teoriya veroyatnostey (Probability theory), Moscow: High school, 1999. 576 p.

Vilenskiy T.V., Khzmalyan D.M., Dinamika goreniya pylevidnogo topliva (The dynamics of the combustion of pulverized fuel), Moscow: Energy, 1978. p.

Yanko I.V., Pirologicheskaya otsenka territorii Tomskoy oblasti (Pyrological assessment of the territory of the Tomsk region). Diss. cand. geogr. sciences. Tomsk: Tomsk State Pedagogical University, 2005, 174 p.

Zakharevich A.V., Zazhiganiye tverdykh $i$ zhidkikh kondensirovannykh veshchestv odinochnymi nagretymi do vysokikh temperatur chastitsami (Ignition of solid and liquid condensed substances by single particles heated to high temperatures), Diss. cand. phys.-mat. sciences, Tomsk: TPU, 2008, $117 \mathrm{p}$.

Zakharevich A.V., Kuznetsov V.T., Kuznetsov G.V., Maksimov V.I., Zazhiganiye model'nykh smesevykh toplivnykh kompozitsiy odinochnoy nagretoy do vysokikh temperatur chastitsey (Ignition of Model Mixed Fuel Compositions of a Single Particle Heated to High Temperatures), Fizika goreniya i vzryva, 2008, Vol. 44, No 5, pp. 54-57.

Reviewer: PhD in technology, associate professor Goman P.N. 